UDC 378.147:81'243

\title{
EFFECTIVE WRITING OF STUDENTS OF TECHNICAL SPECIALTIES
}

\author{
O. S. Synekop \\ Kyiv, National Technical University of Ukraine "Kyiv Polytechnic Institute" \\ oksana.synekop@gmail.com
}

\begin{abstract}
The paper deals with the problem of teaching writing the students of technical specialties in the conditions of interdisciplinarity. The achievements in the field of teaching writing are given. The effective ways of writing texts by the students of higher technical educational institutions are considered. To achieve successful and effective written communication it is necessary to pay attention to the audience; the purpose of writing; researching the topic; focusing the ideas; information organization and content. The audience backgrounds, interests, the level of education and familiarity with the subject have to be taken into consideration by authors. For defining the purposes of the texts it is necessary to follow the scheme "style $\rightarrow$ genre $\rightarrow$ sub-purposes". Researching the topic means collecting information from different sources and processing it. Gathering information is realized on the base of the interdisciplinary approach. The Internet is considered to be the dynamic environment that suggests various information for writing. There are different ways of searching information on the Internet: the search by topics; the keyword search (with the help of search engines or a metasearch engine); the search by links. For focusing the ideas it is possible to use different tools such as brainstorming, freewriting and mindmap. Information organization of the text is considered as the structural foundation of writing that guides readers through the text and helps them to understand the progression of author's thoughts. It focuses on the structure of the text and using connective elements.
\end{abstract}

Key words: teaching writing; higher technical educational institutions; texts; audience; the purpose of writing; researching the topic; focusing the ideas; information organization; content.

Introduction. Nowadays the rapid changes in the information area and interdisciplinarity of contemporary science influence on educational processes in the higher technical educational institutions that are the base of the future high-tech innovative development of Ukraine. That is why training highly qualified specialists that can become competitive and meet the needs of the society is the main aim of educational policy. Experience, skills in a certain technical field of knowledge and mastering foreign languages are the key points of specialists' qualification.

Teaching foreign languages in higher technical educational institutions is closely connected with training technical disciplines. All the foreign authentic material from different subjects starting with physics and mathematics and ending by, for instance, information security, is vocational oriented. Furthermore, the material in a foreign language is presented as it appears on the lectures and practical classes of the fundamental and vocational oriented disciplines in the mother tongue of the students. So, the foreign language combines not only humanitarian knowledge but also technical ones.

The foreign language acquisition involves the ability to communicate in oral and written forms. Now with the development of information technologies in the field of professional communication the role of English writing is increasing. It is an inseparable part of teaching English the students of technical specialties. Studying at the university the students learn how to write various texts from essays and newspaper articles to letters, resumes, research papers, etc. with the aim of solving different learning and professional tasks.

Various issues connected with teaching writing have been considered by scientists and methodologists: J. Harmer (defined writing as a process) [2]; K. Heritage (recommended the stages of the reports writing) [3]; R. M. Howard (focused on the collaborative pedagogy) [5]; P. B. Lowry, A. Curtis and M. R. Lowry (suggested a taxonomy of collaborative writing) [7]; D. E. Zemach and L. A. Rumisek (described the ways of essay writing) [10] and others. Nevertheless, the issues connected with teaching writing the technical students are still open for investigation.

So, the aim of this paper is to outline the effective ways of writing texts by the students of higher technical educational institutions in the conditions of interdisciplinary teaching.

Overview. In fact, writing is known to be one of the most important means of communication. Written communication can be realized only through interaction between two or more participants where one of them is a writer and the other one(s) - a reader / readers. And to 
communicate successfully it is necessary to understand the ways of creating texts in the written form by the students of technical specialties.

Let's consider the effective ways of technical written communication. The word effective in the context of writing means having the clear, accurate, concise logically organized and complete text. To achieve successful and effective written communication a writer / an author has to pay attention to:

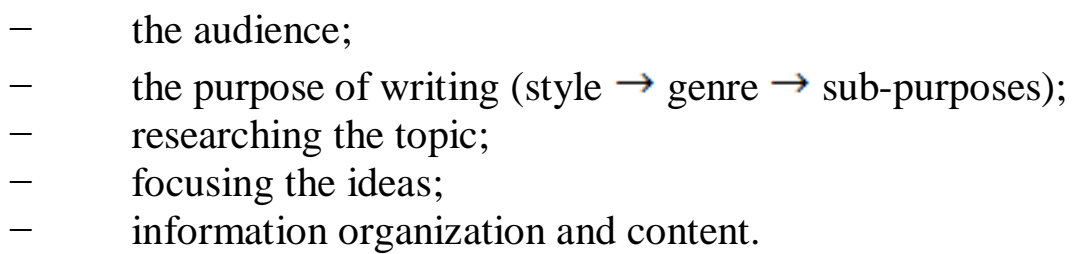

The first point in the list is the audience to which the written product is addressed. The purpose of writing isn't only connected with doing a certain task in the written form but also realizing the long-range purpose - to communicate to a particular audience. It means that the writer or the author has to know the potential readers who are going to read the information. The author should consider audience backgrounds, interests, the level of education, familiarity with the subject. The audience of the students of higher technical educational institutions has concerns from theoretical points to actual practical scientific research in academic laboratories. And the more thoroughly the writer chooses and expresses information, the better the reader understands the suggested information.

The next point is to understand the purpose of writing that means why the student writes. Written communication supposes achieving some aims. The methodical literature suggests different classifications of aims. For instance, A. S. Hill outlines the following modes: description (people or things), narration (acts or events), exposition (analysis or explanation) and argument (conviction or influence) [4]. At the same time B. Wasko uses the same three purposes except the last one. Instead of argument he suggests the purpose of persuasion which means persuasive writing [9]. D. Zimmerman mentions that scientific and technical writing can be differentiated as being either informational or instructional in purpose. Nevertheless, the scientist defines the third category documentation for legal purposes. Also, the scientists think that the author can write to express, explore, entertain, inform / explain, argue for or against an idea / persuade, evaluate / problem solve, mediate / negotiate [11]. According to J. Moxley, there are ten reasons when people write documents (record, reflect / explore, inform, demonstrate knowledge, summarize, explain, analyze, persuade, theorize, entertain) [8]. R. Johnson-Sheehan and Ch. Paine differentiate two purposes (to be informative or to be persuasive) which can be broaden to more specific purposes. So, the informative purpose includes: to inform, to describe, to define, to review, to notify, to instruct, to advise, to announce, to explain, to demonstrate, to illustrate. The persuasive purpose contains the following: to persuade, to convince, to influence, to argue, to recommend, to change, to advocate, to urge, to defend, to justify, to support [6]. All these classifications of writing purposes present different approaches to create the texts in various genres.

To be more precise in defining the purposes of the texts it is necessary to follow the scheme "style $\rightarrow$ genre $\rightarrow$ sub-purposes" (see Table 1). Taking into consideration the fact that technical students study how to write different types of texts it is necessary to define the style, genre and then sub-purposes of these texts. Most of the texts can be joined into three groups of style. They are scientific, official and publicistic. According to these styles, it is possible to outline the genres of the texts and their sub-purposes.

For example, such texts as a research paper, a summary, a report, a thesis, a specification, a review and conference proceedings belong to the scientific style and are written by students with the research aim that allows them to solve the specific purposes in their texts, for example, to explain, to define, to classify, to contrast, to generalize, to evaluate, to summarize, to describe, to illustrate, to prove, to instruct, to analyse.

Also, the students get knowledge how to create business letters, Curriculum Vitae and bibliography that are referred to the official style. So, the main aim of such texts is informational 
that can be broaden to sub-aims: to give information, to complain, to apply for, to advise, to recommend, to record.

Such texts as essays, blog posts, entries that belong to the publicistic style have an educational purpose with its sub-purposes to express, to influence, to convince, to persuade, etc.

However, writing a research paper students not only follow the aim to analyse some data but also to inform the reader about his/her achievements. That is why the methodologists think that the writers can combine different purposes in the text.

The next important point that provides the effectiveness in writing is researching the topic. It means gathering the relevant information from papers and electronic books, newspapers, videos, etc. and processing it. The collection of information can be carried out on the base of the interdisciplinary approach which includes considering frontier and complex objects representing the subject of research for a variety of fundamental and vocational oriented disciplines.

Table 1

STYLES, GENRES AND SUB-PURPOSES OF THE TEXTS

\begin{tabular}{|c|c|c|}
\hline \multicolumn{3}{|c|}{ STYLES } \\
\hline scientific & official & publicistic \\
\hline \multicolumn{3}{|c|}{ GENRES } \\
\hline $\begin{array}{l}\text { report, thesis, instruction, } \\
\text { specification, abstract, } \\
\text { summary, research paper, } \\
\text { resume, review, conference } \\
\text { proceeding }\end{array}$ & $\begin{array}{l}\text { business letter, Curriculum } \\
\text { Vitae, bibliography }\end{array}$ & essay, blog post, entry \\
\hline \multicolumn{3}{|c|}{$\begin{array}{l}\text { SUB-PURPOSES OF THE TEXTS } \\
\end{array}$} \\
\hline $\begin{array}{ll}\checkmark & \text { to inform } \\
\checkmark & \text { to explore } \\
\checkmark & \text { to explain } \\
\checkmark & \text { to define } \\
\checkmark & \text { to classify } \\
\checkmark & \text { to contrast and compare } \\
\checkmark & \text { to generalize } \\
\checkmark & \text { to evaluate } \\
\checkmark & \text { to summarize } \\
\checkmark & \text { to describe } \\
\checkmark & \text { to illustrate } \\
\checkmark & \text { to prove } \\
\checkmark & \text { to instruct } \\
\checkmark & \text { to analyse } \\
\checkmark & \text { to review } \\
\checkmark & \text { to systematize }\end{array}$ & $\begin{array}{ll}\checkmark & \text { to give information } \\
\checkmark & \text { to record } \\
\checkmark & \text { to advise } \\
\checkmark & \text { to provide / make } \\
& \text { suggestions } \\
\checkmark & \text { to complain } \\
\checkmark & \text { to apology } \\
\checkmark & \text { to review } \\
\checkmark & \text { to apply for } \\
\checkmark & \text { to respond }\end{array}$ & $\begin{array}{ll}\checkmark & \text { to educate } \\
\checkmark & \text { to inform } \\
\checkmark & \text { to influence } \\
\checkmark & \text { to convince } \\
\checkmark & \text { to persuade } \\
\checkmark & \text { to demonstrate } \\
& \text { understanding } \\
\checkmark & \text { to explain } \\
\checkmark & \text { to compare and contrast } \\
\checkmark & \text { to identify a problem and } \\
\checkmark & \text { propose a solution } \\
\checkmark & \text { to express a personal } \\
& \text { opinion }\end{array}$ \\
\hline
\end{tabular}

The Internet, as one of the most important and richest sources of information, is considered to be the dynamic environment, in which information is constantly appears and disappears.

Nevertheless, the task of search and selection sometimes appears a complicated task. That is why the author has to outline the points important for the search. For example, to define the known facts of the problem, that the author is looking for; to find general or specific information about the topic; etc.

There are different ways of searching information on the Internet. Among them there is the search by topics. This type of search is used, as a rule, in cases where it is known only the search direction and the need to have a general idea of the resources available on a given topic. In this case, the thematic collection of search sites can be used.

The next way is the keyword search that is realized by search engines. This type of search is the most flexible and powerful and allows the author to search for information on the Web devoted 
to the most diverse, including highly specialized topic. At the same time, the choice of keywords to help users quickly to find exactly what they need rather complicated.

The keyword search can also be performed using a metasearch engine. Metasearch engines transmit one query to multiple search engines at the same time enabling to search for information in multiple databases.

The search by links is also an acceptable way of looking for information. Internet sites are known to be linked via hyperlinks. This search method is rather time consuming, but often brings good results.

After finding necessary information it is necessary to process it: taking notes, paraphrasing, using quotations, etc.

For focusing the ideas it is possible to use different tools such as brainstorming (the process for generating ideas around a specific topic), freewriting (a pre-writing tool, that supposes writing ideas without regarding spelling and grammar rules) or mindmap (a diagram of ideas created around one problem).

The fifth point is information organization and content. Organization of the text can be considered as the structural foundation of writing that guides readers through the text and helps them to understand the progression of author's thoughts. It focuses on the structure of the text and using connective elements.

As a rule, the structure of the text includes the introduction, the main body and conclusions. The aim of the introduction is to direct readers to the purpose of writing, to show the importance of the topic, to interest the readers to read further. To draw attention of readers in the opening sentences, the author can give a thesis or suggest innovative ideas, descriptions, interesting thoughts, etc. The main body covers factual information that is developed in separate paragraphs. Conclusions summarize information in several ways: to repeat the statement reflected in the text; to outline perspectives; to make recommendations.

Using connective elements gives an opportunity the author to present the text as linked, complete and developed in clear progression paragraphing (all the paragraphs are connected with the basic statement of the text), logical expression of ideas (supporting arguments, using examples, linking words, structuring the sentences in which the second part is a focus of the next sentence).

Content of the text should be characterized as concise, precise, relevant, complete, well-organized and illustrated (tables, diagrams, quotations, figures) which are achieved by using sequence, analysing, generalizing, comparison, description, cause and effect, contrast, etc.

Conclusions. To sum up, it is evident from the above points that the effectiveness in students' writing in the conditions of interdicsiplinarity can be achieved due to taking into consideration the audience, the purpose of writing (style $\rightarrow$ genre $\rightarrow$ sub-purposes); researching the topic; focusing the ideas; information organization and content.

The next our step in researching the ways of effective and successful writing is considering the techniques of revising, editing and proofreading.

\section{REFERENCES}

1. Cali, K. \& Bowen, K. (2015). The five features of effective writing. Retrieved from: http://www.learnnc.org/lp/editions/few/cover

2. Harmer, J. (1999). How to Teach English: An introduction to the practice of English language teaching. Longman.

3. Heritage, K. (2003). Report Writing in a week. Hodder \& Stoughton.

4. Hill, A. Sh. (1985). The Principles of Rhetoric. American Book Company.

5. Howard, R. M. (2001). Collaborative Pedagogy. Composition Pedagogies: A Bibliographic Guide. Ed. Gary Tate, Amy Rupiper, and Kurt Schick. New York: Oxford UP., 54-70.

6. Johnson-Sheehan, R. \& Paine, Ch. (2009). Writing Today. Longman.

7. Lowry, P. B., Curtis, A. \& Lowry, M. R. (2004). A Taxonomy of Collaborative Writing to Improve Empirical Research, Writing Practice, and Tool Development. Journal of Business Communication (JBC), 41(1), 66-99.

8. Moxley, J. (2015). Consider Your Purpose. University of South Florida. Retrieved from: http://writingcommons.org/open-text/writing-processes/think-rhetorically/713-consider-your-purpose

9. Wasko, B. (2012). Writing Modes: The four Purposes of Writing. Retrieved from: http://blog.writeathome.com/index.php/2012/02/writing-modes-the-four-purposes-of-wr 
10. Zemach, D. E. \& Rumisek, L. A. (2005). Academic Writing from paragraph to essay. Macmillan.

11.Zimmerman, $\quad$ D. $\quad$ (2015). $\quad$ Types of Purpose. Retrieved from: http://writing.colostate.edu/guides/page.cfm?pageid=25\&guideid=5

О. С. Синекоп. Ефективне писемне мовлення студентів технічних спеціальностей. Стаття присвячена проблемі навчання писемного мовлення студентів технічних спеціальностей в умовах міждисциплінарності. Розглянуті досягнення в галузі навчання письма. Визначені ефективні шляхи написання текстів студентами немовних вищих навчальних закладів. Для досягнення успішного та ефективного письмового спілкування необхідно звертати увагу на аудиторію, якій адресується текст; мету написання; дослідження теми; фокусування ідей; організацію інформації і зміст тексту. Знання аудиторії, іiі інтересів, а також рівня освіченості та обізнаність з проблематикою повинні бути враховані автором. Для визначення цілей текстів необхідно дотримуватися схеми "стиль $\rightarrow$ жанр $\rightarrow$ під-цілі". Для досягнення ефективності у письмі необхідно враховувати такий фактор, як дослідження теми. Дослідження теми передбачає збір інформації 3 різних джерел та іiі обробку. Збір інформації здійснюється з урахуванням міждисциплінарності. Інтернет вважається динамічним середовищем, що надає різноманітну інформацію для створення текстів. $€$ різні способи пошуку інформації в Інтернеті: пошук за темами; пошук за ключовими словами (за допомогою пошукових або метапошукових систем); пошук за посиланнями. Для фокусування ідей використовується різний інструментарій такий, як мозковий штурм, вільне письмо та інтелектуальна карта. Організація інформації передбачає написання тексту за структурою, а також використання зв'язок, що допоможуть читачам зрозуміти текст та відслідковувати розвиток ідей автора.

Ключові слова: навчання письма; міждисциплінарність; немовні вищі навчальні заклади; тексти; аудиторія; мета письма; дослідження теми; фокусування ідей; відомості про організація інформації; зміст.

\section{О. С. Синекоп. Эффективная письменная речь студентов технических специальностей.}

Статья посвящена проблеме обучения письменной речи студентов технических специальностей в условиях междисциплинарности. Рассмотрены достижения в области обучения письму. Определены эффективные пути написания текстов студентами неязыковых вузов. Для достижения успешного и эффективного письменного общения необходимо обращать внимание на аудиторию, которой адресуется текст; цель написания; исследование темы; фокусировку идей; организацию информации и содержание текста. Знание аудитории, ее интересов, а также уровня образованности и осведомленность с проблематикой должны быть учтены автором. Для определения целей текстов необходимо придерживаться схемы “стиль $\rightarrow$ жанр $\rightarrow$ под-цели”. Для достижения эффективности в письме необходимо учитывать такой фактор, как исследования темы. Исследование темы предусматривает сбор информации из различных источников и ее обработку. Сбор информации осуществляется с учетом междисциплинарности. Интернет считается динамичной средой, которая предоставляет разнообразную информацию для создания текстов. Есть разные способы поиска информации в Интернете: поиск по темам; поиск по ключевым словам (с помощью поисковых или метапоисковых систем); поиск по ссылкам. Для фокусировки идей используется разный инструментарий такой, как мозговой штурм, свободное письмо и интеллектуальная карта. Организация информации предполагает написание текста по структуре, а также использование связок, которые помогут читателям понять текст и понять развитие идей автора.

Ключевые слова: обучение письменной речи; междисциплинарность; неязыковые высшие учебные заведения; тексты; аудитория; цель письма; исследования темы; фокусировка идей; организация информации; содержание. 